\title{
The Neural Cell Adhesion Molecule F3: An Axonal Glycoprotein Promoting Neurite Outgrowth
}

\section{神経細胞接着分子F3：神経突起伸長を促進させる軸索糖タンパク質}

\author{
${ }^{1,2)}$ Gennarini, G., and ${ }^{2)}$ Rougon, G. \\ 1)Istituto di Fisiologia Umana-Università di Bari, Italy, FAX: 39-80-27-8416, and ${ }^{2)}$ Laboratoire de Génètique et Physiologie du \\ Développement, CNRS 9943-Marseille, France, FAX: 33-9126-9380
}

Key Words: axonal glycoprotein, immunoglobulin supergene family, cultured neuronal cell, F3 neural adhesion molecule, neurite outgrowth

\begin{abstract}
$\mathrm{F} 3$ is a $135 \mathrm{kDa}$ glycoprotein expressed at the surface of cultured neuronal cells and released in soluble form in the culture medium. Its structural properties, mainly derived from biochemical and molecular biology studies, revealed that it belongs to two families of cell interaction molecules: the HNK-1 family and the immunoglobulin supergene family. In particular, F3 is built of two kinds of distinct domains: Immunoglobulin type C2 and Fibronectin type III ones. This association is often found in the case of those surface glycoproteins bearing a predominant axonal localization. Accordingly, F3 expression was mainly restricted to neurites in brain primary cultures and to axon tracts in vivo. The molecule expression was found to be developmentally regulated with a peak in phases of the postnatal development characterized by extensive axonal growth and synaptogenesis. Functionally, we demonstrated its ability to mediate heterophilic interactions between nerve cells and to control key developmental processes as neurite outgrowth. On the basis of the above data we suggest that regulation of F3 gene expression during development is provided of key significance in neural morphogenesis.
\end{abstract}

\section{A. Introduction}

The development of the nervous tissue depends upon the complex interplay between a number of spatially and temporally coordinated events which include precursor cell migration through preformed pathways, their aggregation in clusters of defined functional significance and the acquisition of a specific phenotype both in terms of neurotransmitter choice and cell morphology. The final outcome of this differentiation program is the generation of specific patterns of neural connections which characterize different brain regions in definite developmental stages.

One of the central problems of the developmental neurobiology concerns the identification of the molecular events underlying the specific organization of the neural pathways. This in turns includes the general topic of the molecular control of
要 約

F3は培養神経細胞の表面に存在し、可溶性の分子として培 地にも放出される $135 \mathrm{kDa}$ の糖タンパク質である。生化学的研究 と分子生物学的研究から、この分子がHNK-1ファミリーとイム ノグロブリンスーパージーンファミリーという細胞間相互作用 に関与する分子の二つのファミリーに属することが明らかと なっている。さらに、F3はイムノグロブリンC2型とファイブロ ネクチンIII型という異なる二種のドメインを持っている。この 組合せは、主に軸索表面に局在する糖タンパク質にしばしばみ られるものである。F3の発現も初代培養脳細胞では主に神経突 起に、in vivoでは軸索路に限局されている。この分子の発現 は、軸索伸長とシナプス形成が起こる生後発生の時期にピーク を持つように制御されていることが分かっている。機能的には 神経細胞間のヘテロフィリックな相互作用を媒介し、神経突起 伸長のような基本的な発生現象を制御しうることが示されてい る。以上の事実は、発生過程におけるF3発現の制御が神経系の 形態形成において基本的な重要性を持つことを示唆している。

A. はじめに

神経組織の発生は、いくつかの空間的、時間的に統合され たできごとの複雑な相互作用に依存している。そのできごとに は、すでにある経路を前駆細胞が移動することや、細胞が特定 の機能集団を形成することや、神経伝達分子の選択と細胞の形 態について特定の表現系を獲得することが含まれる。この分化 プログラムによって最終的には、ある発生段階の脳の部位に特 徵的な神経連絡パターンが形成される。

発生神経生物学の中心課題の一つは、神経回路形成の分子 メカニズムに関するものである。これは、シナプス結合の特異 性を制御する分子メカニズムという一般的な問題を含んていい 
Trends in Glycoscience and Glycotechnology Vol. 5 No. 26 (November 1993) pp. 450-465

the synaptic specificity. It is today largely accepted that the specificity of neural connections is largely dependent upon the spatial and temporal regulation of a number of cell surface glycoproteins which structurally belong to distinct gene families and functionally respond to the operational definition of adhesion molecules because of their demonstrated ability to mediate cell contacts formation (1). The actual definition of adhesion molecule however has probably lost most of its initial significance, the adhesion event in itself appearing rather as an epiphenomenon within a complex biological role including the generation of differentiation signals involved in the control of neural morphogenesis. It is therefore probably more appropriate to apply to the adhesion receptors the general denomination of morphoregulatory molecules (2).

\section{B. The Neurite Outgrowth as an Adhesion Dependent De- velopmental Process}

Neurite outgrowth is probably the best known among the adhesion dependent events occurring during neuromorphogenesis. Adhesion molecules belonging to distinct gene families have been found to promote processes extension in various in vitro systems. Of these the most extensively used include the culture of primary neurons on inert supports bearing immobilized adhesive glycoproteins (3) or on monolayers of adhesive molecules expressing transfected cells (4). Since adhesive glycoproteins normally display different binding specificities, it is generally believed that the positive effects they exert on neurite outgrowth is mediated via their convergence on similar second messengers pathways (5); in some instances however the underlying signalling mechanisms were suggested to be different for structurally distinct morphoregulatory molecules (6). Although the generation of transmembrane signals is likely to account for most of the outgrowth promoting effects of morphoregulatory molecules, an alternative although not exclusive explanation is based on the assumption that adhesion of the growing neurite tip to the extracellular surfaces promotes its protrusion via the generation of mechanical forces within the extending process (7).

Most of the presently available functional data about the neurite outgrowth promoting molecules concern immunoglobulin superfamily components as exemplified in the case of the Neural Cell Adhesion Molecule, NCAM which stimulates processes extension via a complex signalling mechanism involving the activation of calcium channels (8). Moreover, the NCAM dependent outgrowth mechanism undergoes developmental regulation in that the molecule from the earliest stages of development displays an increased ability to promote neuronal differentiation. Tacken toghether with the known ontogenetic regulation of the NCAM glycosylation state these data clearly support the view that the NCAM promoting effect could
る。神経間結合の特異性は、細胞表面のいくつかの糖タンパク 質の空間的、時間的制御に大きく依存していることが今日広く 認めらている。それらの糖タンパク質は、構造的にはいくつか の異なる遺伝子ファミリーに属し、細胞間の接触を媒介すると いう機能から接着分子と命名されている(1)。しかしながら、こ の接着分子という命名は、この分子の第一の重要性を見失わせ ている。というのは、接着それ自体は、むしろ神経系の形態形 成を制御する分化シグナルを起こすという複雑な生物学的役割 の内の一現象であると考えられる。そこで接着レセプターに対 しては、形態形成制御分子と命名する方がより適当であると思 われる(2)。

\section{B. 接着依存性の過程としての神経突起伸長}

神経突起伸長は、神経形態形成中に起こる接着依存性のて きごとの内で最もよく知られているものである。異なる遺伝子 ファミリーに属する接着分子が、in vitroの系で突起伸長を起こ させることが示されている。最もよく用いられる系は、初代培 盖神経細胞を、接着糖タンパク質を固定化した基質の上か(3)卜 ランスフェクトした細胞の上に培養する(4)ものである。接着糖 タンパク質は通常異なる結合特性を示すので、それらの分子が 示す神経突起形成の促進効果は一般に類似のセカンドメッセン ジャーへの収束を介していると考えられている(5)。しかしなが ら、ある場合には、構造的に異なる形態制御分子間では情報伝 達メカニズムは異なるものであることが示唆されている(6)。膜 を介したシグナルの発生は、形態制御分子の多くの突起伸長効 果を説明すると思われるが、成長する神経突起の先端が細胞外 の基質に結合することが突起伸長の機械的な力となっていると いう仮定に基づいた説明もあり得る(7)。

現在得られる神経突起伸長を促進させる分子の機能につい てのデータのほとんどがイムノグロブリンスーパーファミリー に関するものである。たとえば、カルシウムチャネルの活性化 を介した情報伝達メカニズムによって突起伸長を促す神経細胞 接着因子、NCAMなどがある(8)。さらに、NCAM依存性の突起 伸長メカニズムは、発生過程で最も初期に現れる分子がより強 い分化促進活性を示すという様に発生過程において制御を受け ている。NCAMのグリコシル化状態の発生過程における変化を 考えると、NCAMによる突起伸長活性は自身のグリコシル化量 
Trends in Glycoscience and Glycotechnology Vol. 5 No. 26 (November 1993) pp. 450-465

be controlled via its sugar content. In particular a definite relationship has been demonstrated between the NCAM neuraminic acid content and its ability to promote neuronal differentiation (9). Although the exact mechanism underlying this kind of relationship is largely unknown, the antiadhesive effects exerted by the polysialic acid moiety could be involved. Cell adhesion and its reverse effect, i.e. adhesion inhibition, are indeed both considered of key functional significance in the control of the morphogenetic effects exerted by some adhesive glycoproteins and this is especially the case for neurite outgrowth $(10,11)$.

\section{B. The F3 Glycoprotein}

In recent years we have been working to the characterization of the structural and functional properties of the mouse F3 glycoprotein, a cell surface molecule mainly expressed by a subpopulation of central and pheripheral neurons.

The identification of F3 was the outcome of a large research project focused on the functional characterization of the glycoproteins expressed at the surface of cultured neuronal cells (12). In this study, which also led to the identification of mouse NCAM, F3 stood out because of a series of structural and biological features. These included i) the occurrence of the molecule at the neuronal cell surface as one of its main constituents; ii) the ability of the molecule to be spontaneously released in the primary cultures medium which represented an elective source for its isolation; iii) the presence on the molecule of the L2/HNK-1 epitope, a sulfated glucuronic acid containing sugar moiety, shared by a restricted number of surface or extracellular matrix components both in the immune and nervous tissue $(13,14)$. Most of these molecules are glycoproteins in nature and their involvement in cell to cell or cell to matrix interactions has been largely documented. The hypothesis was therefore put forward that the HNK-1 epitope itself could be involved in the adhesive events as a cell surface ligand via interaction with a heterophilic receptor (15-16). The same carbohydrate structure could indeed be detected on some glycolipids (17). As far as the functional role of HNK-1 is concerned, Hynes et al. (18) suggested the following possibilities: i) the epitope itself could represent a ligand for $\beta$-galactoside binding lectins; ii) the presence of HNK-1 on a glycoprotein could promote the adhesion process of its protein backbone; iii) the epitope could play a role as a recognition signal involved in the targeting of some glycoproteins to precise cell surface areas. Although neither of these proposed roles has been definitely confirmed, this sugar epitope can at least be considered as a marker of some adhesive glycoproteins.

To get more insigths on the functional significance of $F 3$ expression during neural morphogenesis the molecule's structural, biological and functional properties were investigated by a pluridisciplinary study performed at the biochemical, cellular
によって制御されているという可能性が強く支持される。特に NCAMのシアル酸量と神経分化活性との間には明かな関係があ ることが証明されている(9)。この関係に関する正確な機構はよ く分かってはいないが、ポリシアル酸による抗接着効果が考え られている。細胞接着とその逆の接着阻害は、接着糖タンパク 質が関与する形態形成制御において、基本的機能として重要で あると考えられ、これは特に突起伸長について言えることであ る(10、11)。

\section{B. F3糖タンパク質}

近年、我々は主に中枢と末梢の一部の神経細胞に発現して いる細胞表面分子、マウスF3糖タンパク質の構造と機能の特徴 について研究してきた。

F3は、培養神経細胞表面に存在する糖タンパク質の性質を 調べる大きな研究プロジェクトの中で同定された(12)。マウス NCAMも同定されたこの研究において、F3はきわだった一連の 構造的、生物学的特徵を示した。それは、i)神経細胞の表面分 子の主要構成成分として存在すること、ii) 初代培養の培地に放 出され、その培地が精製の出発材料となること、iii)免疫組織や 神経組織のいくつかの細胞表面分子もしくは細胞外マトリック ス分子に見いだされる硫酸化グルクロン酸を含む糖構造である L2/HNK-1エピトープが存在すること(13、14)などである。これ らの分子のほとんどが糖タンパク質であり、多くが細胞間もし くは細胞基質間相互作用に関わることが示されている。そこ で、HNK-1エピトープそれ自身がヘテロフィリックなレセプ ターと相互作用し、細胞表面リガンドとして接着に関わるとい う仮説が提唱されている(15、16)。同一の糖鎖構造が、ある種 の糖脂質にも見い出されている(17)。HNK-1エピトープに関し てHynesら(18)は、次の可能性を示唆している。i)そのエピトー プ自身が、ß-ガラクドシド結合レクチンのリガンドとなりう る。ii)糖タンパク質上にHNK-1エピトープが存在することは、 タンパク質部分の接着を促進しうる。iii)そのエピトープは、あ る糖タンパク質が正確にある細胞表面領域に行くための認識シ グナルとして機能しうる。これらの提唱された役割は、どれも きちんと確認されてはいないが、この糖鎖エピトープは少なく ともある種の接着糖タンパク質のマーカーと考えることができる。

神経系の形態形成におけるF3発現の重要性についてより多 くを知るために、F3分子の構造的、生物学的、機能的特性につ いて生化学的、細胞学的、分子生物学的レベルという多くの領 
and molecular biology levels.

\section{Structural Features of the F3 Glycoprotein}

$\mathrm{F} 3$ is a $135 \mathrm{kDa}$ glycoprotein expressed at the surface of cultured neuronal cells, released in soluble form in the culture medium and detected, in brain extracts, in both soluble and membrane-associated forms $(12,19)$.

The definition of the F3 structural organization was the result of the cloning of its full length cDNA by a classical approach consisting in the antibody screening of a lambda gt 11 expression library (12). The overall organization of the molecule is shown in Fig. 1. The aminoterminal half is organized in six immunoglobulin-like domains which, according to Williams (20) and Williams and Barclay (21), could be classified in the $\mathrm{C} 2$ subtype, a kind of immunoglobulin domain sharing intermediate properties between the constant and variable Ig regions. Most of the putative $\mathrm{N}$-glycosylation sites are located within the Ig-like region (the molecule bear 9 of such consensus sequences, 8 of which are localized within the Ig domain 2 to 6). This was responsible for a $20 \% \mathrm{Mr}$ shift upon endoglycosidase F digestion (19). The Ig-like region is followed by a short proline and glycine rich stretch, structurally similar to the "hinge" region occurring in the immunoglobulins (22) and in most immunoglobulin-like molecules. This sequence, which could specify the orientation of the $\mathrm{N}$-terminal Ig region within the plane of the membrane, is likely to play an important role in modulating the complex"cis"and"trans"F3 interactions. The $\mathrm{C}$-terminal half carries four sequences showing homologies with the fibronectin type III domains (23), a repeated region which mediates the cell and heparin binding functions of Fibronectin (24). Via their RGD sequences, these domains also bind to extracellular matrix receptors of the integrin family. In the case of F3 however, no RGD sequences were found within
域を含む研究が行なわれた。

\section{F3糖タンパク質の構造の特徵}

F3は、135 kDaの糖タンパク質で、培養神経細胞表面に存 在し、培地に可溶性分子として放出され、脳抽出物中には可溶 性と膜結合性の両方の形で検出される(12、19)。

F3分子の構造は、ラムダ gt11ライブラリーを抗体でスク リーニングするという古典的な方法を用いた全長cDNAのク ローニングにより明らかになった(12)。分子全体の構造は図1に 示してある。アミノ末端半分の構造は、6つのイムノグロブリン 様ドメインよりなる。Williams(20)とWilliams and Barclay(21)の 提唱によれば、これらは、イムノグロブリンの定常領域と可変 領域の中間の特徵を示すイムノグロブリン様ドメインであるC2 サブタイプに分類される。N型グリコシル化可能部位のほとん どは、イムノグロブリン様領域の中に存在する(この分子は9つ のコンセンサス配列を持ち、8つがイムノグロブリン様ドメイン 2から6の中に存在する)。これは、エンドグリコシダーゼF消化 による20\%の分子量減少に対応する(19)。イムノグロブリン様 領域の次には、イムノグロブリン(22)や多くのイムノグロブリ ン様分子にみられるヒンジ領域に構造的に類似のプロリンとグ リシンに富んだ短いストレッチが続く。膜平面上でのN末側イ ムノグロブリン様領域の方向を特定するのに関与するかもしれ ないこの配列は、F3の複雑なシスとトランスの相互作用を調節 する重要な役割を持つ可能性がある。C末側半分には、ファイ ブロネクチンの細胞とヘパリンへの結合機能に関与するファイ ブロネクチンIII型ドメイン(24)と相同性を示す配列が4つある (23)。RDG配列を介してこのドメインはインテグリンファミ リーの細胞外マトリックスレセプターと結合する。しかしなが

F3

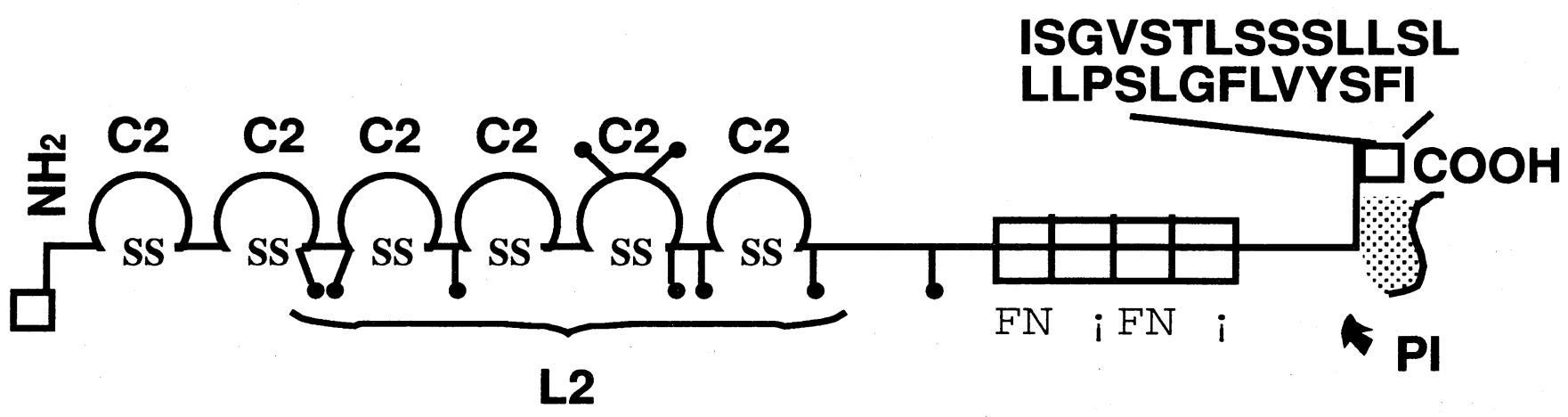

Fig. 1. Structural organization of the mouse F3 Glycoprotein. The molecule bears 6 immunoglobulin type C2 domains in its $N$ terminal region and four type III Fibronectin-like domains in its C-terminal half. I $=N$-glycosylation sites. The hydrophobic amino acid sequence responsible for the GPI attachment is also shown at the $\mathrm{C}$-terminus. 
the type III domains nor elsewhere, thus suggesting that this kind of domain could serve different functions. As far as the general role of the type III domains is concerned, it was suggested that, at least in some instances, they could simply work as "spacers" between the functional region of some surface molecules and the cell membrane. However, more recent studies demonstrated for this repeats a structural organization similar to that of the Ig-like type $\mathrm{C}$ ones, including seven beta strands arranged in two beta sheets (25-27). On the basis of this observation it could be inferred that Ig-like and FN type III domains can serve similar functions and that molecular interactions of the Ig/FN type III glycoproteins could involve both kinds of domains.

The association of Fibronectin type III with the Ig-like domains is typical of, although not diagnostic for, those adhesive glycoproteins of the nervous tissue which display a predominant localization at the axonal level (28). Among them the most extensively characterized is the mouse L1 glycoprotein (29) a neural cell adhesion molecule mediating important morphogenetic events like cell migration (30), neurite outgrowth (31) and fasciculation (32). To the same group belong the $\mathrm{G} 4 / \mathrm{NgCAM}$ glycoprotein, a chick immunoglobulin superfamily component sharing $40 \%$ homology to L1 (33) and the rat TAG-1/axonin-1 an axonal glycoprotein specifically expressed by a neuronal subpopulation such as the commissural spinal neurons $(34,35)$. The similarity of these surface com-
ら、F3の場合はRGD配列をIII型ドメインの中にも持たず、この ドメインが異なる機能に関与することを示唆する。III型ドメイ ンの一般的役割に関しては、膜表面分子の機能領域と細胞膜の 間の単にスペイサーとして働いている場合があることが示唆さ れている。しかしながら、最近の研究により、二つのベータ シートの中に7つのベータストランドを持つ構造など、このドメ インの構造はイムノグロブリン様C型ドメインと類似している ことが明らかにされている(25-27)。この事実から、イムノグロ ブリン様ドメインとファイブロネクチンIII型ドメインが類似の 機能に関与し、分子間相互作用には両ドメインが関与すること が推定される。

イムノグロブリン様ドメインとファイブロネクチンIII型ド メインが同一分子上に存在することは、軸索に局在する接着糖 タンパク質のすべてに言えるわけではないが、特徴となってい る(28)。それらの中で最も性質が調べられているのが、細胞移 動(30)、神経突起形成(31)、繊維束形成(32)のような重要な形態 形成現象に関与している神経細胞接着分子、マウスL1糖タンパ ク質(29)である。同じグループに属する分子としては、L1と 40\%の相同性があるニワトリのイムノグロブリンスーパーファ ミリー分子、 G4/NgCAM(33) と、交連脊骾神経細胞のような一 部の神経細胞に特異的に発現している軸索糖タンパク質、ラッ トTAG-1/axonin-1(34、35)がある。F3に対するこれらの細胞表
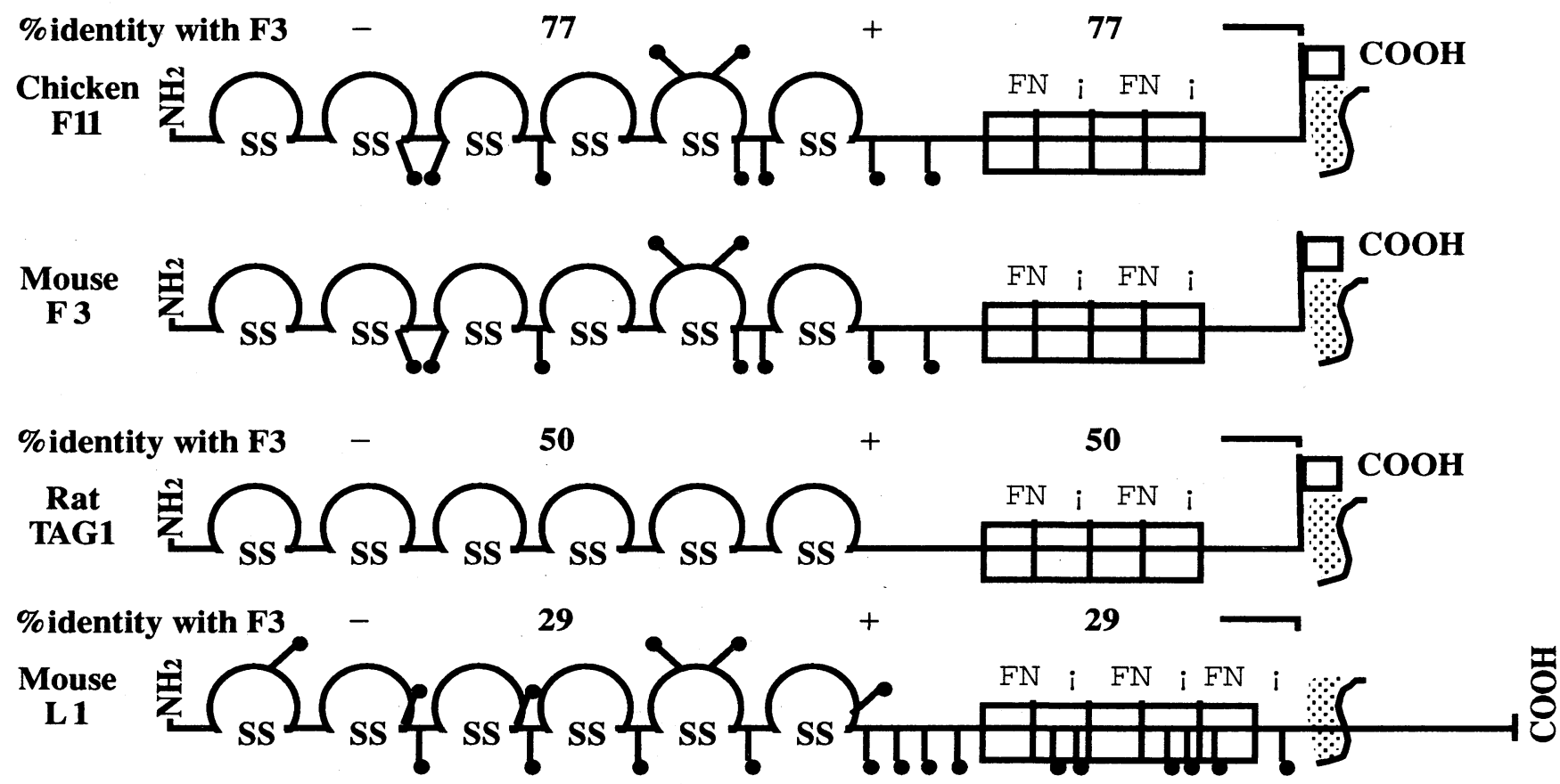

Fig. 2. Structural relationship between some axonal glycoproteins belonging to the Ig superfamily. All of them are built of Ig type $\mathrm{C} 2$ and Fibronectin type III domains. L1 is provided of a classical transmembrane region while F3/F11 and TAG-1/Axonin 1 are GPI anchored molecules. An high level of structural similarity exists between mouse F3 and chick F11 which therefore represent species homologues. 
ponents to $\mathrm{F} 3$ ranges from $29 \%$ (for L1) to $50 \%$ (for TAG-1). The chick F11 glycoprotein (36) stands out among the axonal glycoproteins because of its high level of homology to F3 (77\%) of which it can be considered as the species homologue (Fig. 2).

Although these glycoproteins share the same overall organization, they mainly differ for the structure of their C-terminal region which mediates their association to the cell membrane. L1, G4 and NgCAM are classical type I transmembrane glycoproteins embedded in the bilayer via a hydrophobic amino acid sequence followed by a stop transfer signal and a cytoplasmic tail. On the other hand in the case of F3/F11 and TAG-1/ Axonin-1 the cDNA sequences allowed to predict, at the C-terminus, a stretch of 20 hydrophobic amino acids in the absence of any cytoplasmic domain. This kind of structural feature, although not absolutely diagnostic for, is often shared by those cell surface components anchored to the membrane via a phosphatidylinositol (PI) containing lipid tail. In these cases the C-terminal sequence is cotranslationally cleaved and substituted for the glycosylphosphatidylinositol (GPI) anchor, a complex glycan moiety containing high amounts of mannose and, as a quite peculiar feature, non-acetylated glucosamine (37). The linkage between the GPI group and the protein is made by an ethanolamine bridge between the $\mathrm{C}$-terminal amino acid and an hydroxyl from a terminal GPI mannose residue. The complex glycan moiety is then bound to the inositol ring via its glucosamine residue engaged into a glycosidic linkage. Finally, the inositol residue is linked to a diacyl glycerol residue by a phosphodiesther bond (see Fig. 3). Bacterially derived phos-
面分子の相同性は、29\%(L1)から50\%(TAG-1)である。ニワトリ のF11糖タンパク質(36)は、F3に高い相同性(77\%)を示し種間ホ モログと考えられるので、軸索糖タンパク質の中では突出して 類似している(図2)。

これらの糖タンパク質は全体としては同じ構造をとるが、 細胞膜への結合に関わるC末領域の構造が主に異なる。L1、 G4、NgCAMは、膜扱入停止シグナルと細胞質側の配列が後に 続く、疎水性アミノ酸配列を介して脂質二重相へ固定されてい る古典的なI型膜糖タンパク質である。一方、F3/F11とTAG-1/ Axonin-1の場合は、cDNA配列から、細胞質ドメインはなく、 20残基の疎水性アミノ酸のストレッチがC末にあることが推定 されている。この種の構造的特徴は、全てではないがホスファ チジルイノシトール(PI)脂質を介して膜に結合する細胞表面分 子に共通のものである。この場合には、C末配列は翻訳と同時 に切断され、多くのマンノースと独特なアセチル化されてない グルコサミンを含む複雑な多糖であるグルコシルホスファチジ ルイノシトール(GPI)アンカーに置換される(37)。GPIとタンパ ク質の結合は、C末アミノ酸とGPIの末端マンノースの水酸基の 間のエタノールアミンブリッジにより作られる。多糖部分は、 グリコシド結合によりグルコサミンを介してイノシトールに結 合している。最終的には、イノシトールは、ホスホジエステル 結合によりジアシルグリセロールに結合している(図3)。細菌の ホスファチジルイノシトール特異的ホスホリパーゼC(PIPLC) は、その結合を切断し、PI結合分子を可溶性型として遊離させ

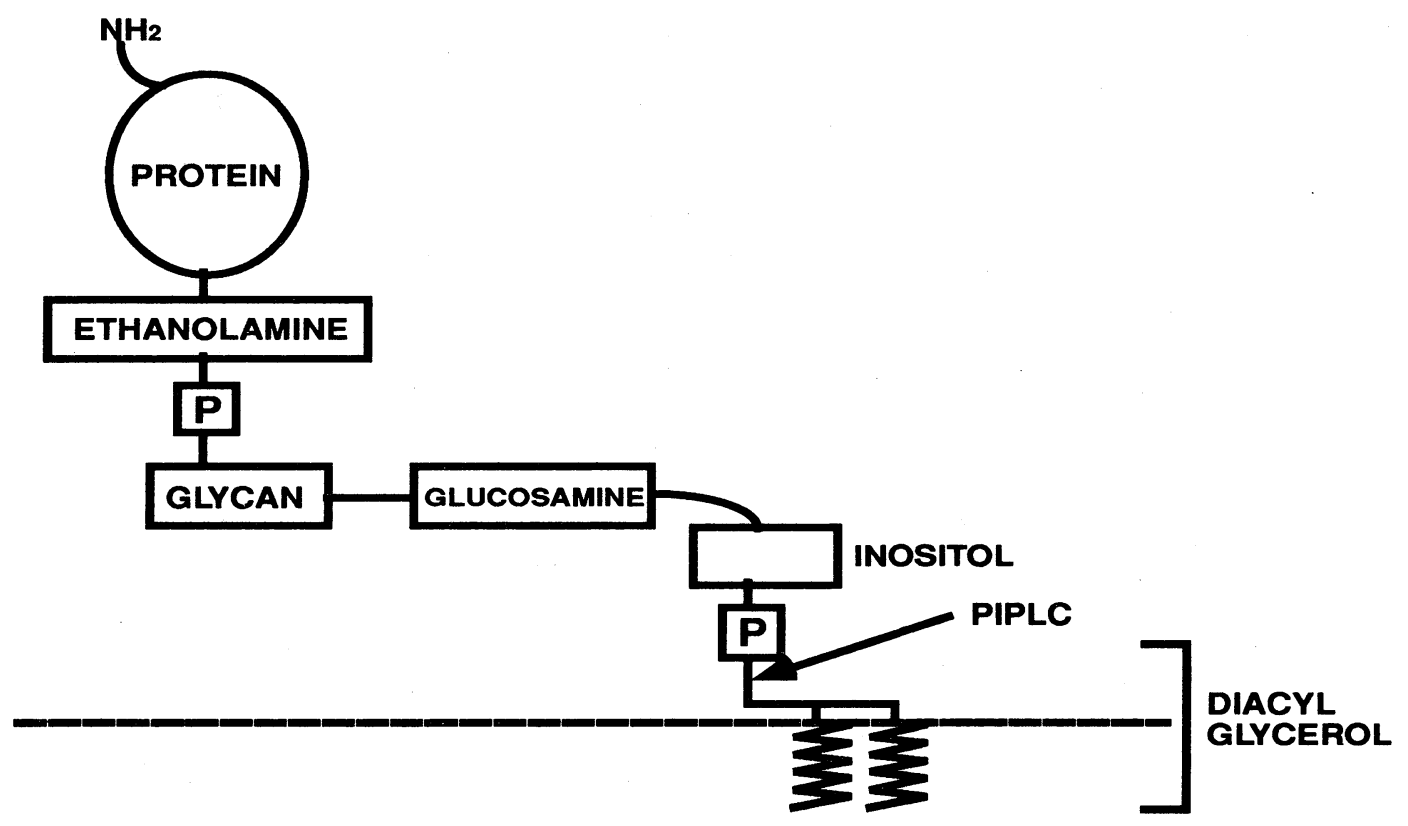

Fig. 3. Composition and structural organization of the GPI anchor. A complex glycan is connected by an ethanolamine bridge to the C-terminal amino acid and by a glycosidic linkage to an inositol residue. This is linked in turn by a phosphodiesther bond (P) to a diacylglycerol residue embedded into the membrane. 
Trends in Glycoscience and Glycotechnology Vol. 5 No. 26 (November 1993) pp. 450-465

phatidylinositol-specific phospholipase C (PIPLC) can specifically cleave such a linkage thus allowing the delivery of PI anchored molecules in soluble form (38). Accordingly, and similarly to the $120 \mathrm{kDa}$ NCAM isoform (39), PIPLC treatment induced the F3 release from brain membranes (19), thus confirming the molecule anchorage by a PI containing lipid tail. The cleavage of the phospholipid anchor could be responsible for the F3 occurrence, in brain extracts, in both soluble and membrane-associated forms, an alternative explanation being the existence of different $\mathrm{F} 3$ isoforms produced by alternative splicing and lacking the $\mathrm{C}$-terminal hydrophobic consensus for GPI anchorage as shown for NCAM (40).

As in the case of other GPI anchored molecules the functional significance of this peculiar type of membrane attachment is poorly understood. It has been postulated that, in neurons as in other kinds of polarized cells the mode of membrane attachment is of critical importance in the intracellular sorting mechanism occurring at the trans-Golgi level and leading to the targeting of surface molecules to either the apical (in neurons, axonal) or basolateral (perikaryon + dendrites) regions (41). Like free glycolipids, GPI anchored molecules would be mainly sorted to the axonal (apical) region. The study of the F3 immunocytochemical distribution in primary cultures maintained in defined medium (19) confirmed this hypothesis since in this system F3, faintly expressed on the cell bodies, was mainly localized at the neurite level. An alternative, although not exclusive interpretation of the functional significance of the PI anchorage rests on the possibility that glycoproteins bearing glycolipid anchors could be released in soluble form and therefore exert, as diffusible factors, their biological effects at a certain distance from the site of their synthesis and delivery.

\section{Biological Properties of F3 \\ D-1. Developmental Pattern}

In one of our earliest studies, F3 stood out as a developmentally regulated glycoprotein. Evidences in this sense were obtained at both the immunohistochemical (12), molecular biology (19) and biochemical (42) levels. F3 was hardly detectable in the embryonic brain while its concentration increased dramatically during the first two postnatal weeks. Around the 14th postnatal day the molecule concentration in brain membranes was about eigthfold higher than in the adult. These changes were likely to be controlled at the transcriptional level, the F3 mRNA undergoing the same developmental changes (19).

In recent years we mainly worked at the study of the F3 immunohistochemical distribution in different developmental stages. Our model was the mouse cerebellar cortex because of the well established organization of definite cell types in its different layers $(12,43)$. We never detected $\mathrm{F} 3$ within the external granular layer which mainly contains proliferating
ることができる(38)。というわけで、NCAMの120 kDaアイソ フォームの場合と同様に(39)、PIPLC処理は、脳の細胞膜から F3を遊離させる(19)。この事実からこの分子がPIを介して膜に 結合していることが確認された。脳抽出物の中で可溶性と膜結 合性の形でF3が存在することを、脂質アンカーの切断により説 明することができるかもしれない。他にも、NCAMにみられる ようなスプライシングの違いにより生ずる、GPIアンカーのた めのC末疎水性コンセンサス配列のないF3アイソフォームが存 在するためと説明することもできる(40)。

他のGPIアンカーされた分子の場合と同様に、この独特な 膜結合の機能上の意味はほとんど分かっていない。他の局性を 持った細胞と同様に神経細胞では、トランスゴルジレベルで起 きる、先端部(神経細胞では軸索)もしくは基側部(細胞体+樹状 突起)への表面分子の局在化を導く細胞内機構において、膜結合 の状態は非常に重要であると考えられている(41)。通常の糖脂 質と同様にGPIアンカーされた分子は、主に軸索(先端)部に運ば れるようである。ある培地で維持された初代培養細胞における F3の免疫組織化学的分布についての研究より、この仮説が確か められた(19)。この系においては、F3は細胞体にも極少量存在 するがほとんどが神経突起に局在していた。他にもPIアンカー の機能的重要性の説明として、糖脂質アンカーを持った糖タン パク質は可溶性の形で放出され、合成され運ばれる場所から距 離をおいて、拡散可能なファクターとして、生物活性を示すこ とができるという可能性が考えられる。

\section{F3の生物学的特徴}

\section{D-1. 発生過程における発現パターン}

我々の初期の研究の一つにおいて、F3は発生過程において 発現が制御されている糖タンパク質として注目された。証拠は 免疫組織化学的(12)、分子生物学的(19)、生化学的(42)レベルで 得られた。F3は胎児脳にはほとんど検出されないが、生後二週 間の間に劇的に増加していた。生後14日あたりでは脳膜画分中 の量は成体の約八倍であった。F3のmRNAが同様に発生変化す ることから、このような変化は、転写レベルで制御されている と考えられた。

近年、我々は主に異なる発生段階におけるF3の免疫組織化 学的分布について研究してきた。我々は、異なる層の限定され た細胞よりなる整然とした構造を持つマウス小脳皮質をモデル とした(12、43)。増殖している神経芽細胞を主に含む外顆粒層 
neuroblasts. By contrast, F3 was heavely expressed on the postmitotic neurons as shown for the migrating granule cells which expressed F3 mostly at the level of their axonal extensions. On the cell bodies the molecule was only transiently expressed as demonstrated by the lack of $\mathrm{F} 3$ in the internal granular layer while, in different developmental stages, F3 antibodies heavily stained the molecular layer, mainly composed by the axonal projections of the granule cells (see Fig. 4). These data confirmed the in vitro indication of a predominant association of F3 with the axonal membranes rather than with the cell bodies.

On the basis of the above results it could be stressed that F3 expression was up-regulated on the axonal structures during developmental periods characterized by intense neurite outgrowth and synaptogenesis thus suggesting the F3 implication in phenomena of key morphogenetic relevance as neurite outgrowth and fasciculation.

\section{D-2. Cell Type Specific Expression and Subcellular Lo- calization.}

In a developmental study performed at the immunoelectron microscopy level in the mouse cerebellar cortex (43), we found that $F 3$ expression was definitely restricted to certain cell types. F3 was completely absent from the Purkinje cells both at the level of their cell bodies and neurite extensions. The same was true for the stellate cells while at the granule cells level the immunostaining was essentially limited to their axonal

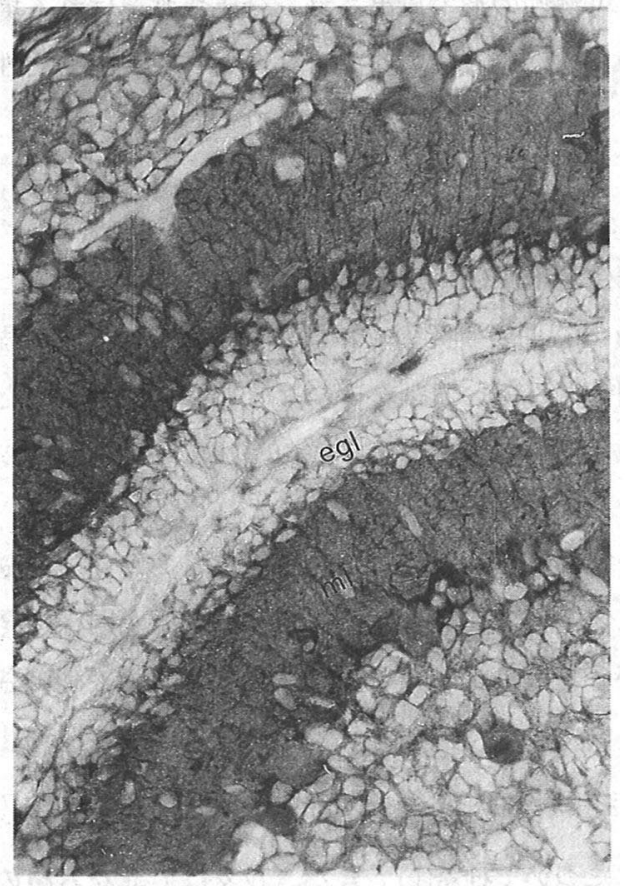

Fig. 4. Immunohistochemical localization of F3 in the 10 day mouse cerebellar cortex. Note the absence of staining in the external granular layer (egl) and its predominant accumulation in the molecular layer $(\mathrm{ml})$.
にはF3は見い出されなかった。それとは逆に、F3は、軸索にF3 を最も発現している移動中の顆粒細胞のような分裂後の神経細 胞に強く発現していた。内顆粒層におけるF3の欠失からわかる ように、この分子は細胞体には一過性にしか発現せず、異なる 発生段階においては、F3に対する抗体は主に顆粒細胞の軸索よ りなる分子層を強く染めた(図4)。これらのデー夕はin vitroにお いてF3が細胞体より軸索膜に存在することとよく一致した。

上述の結果は、F3の発現が、盛んな神経突起伸長とシナプ ス形成で特徴づけられる発生時期に軸索上で上昇していること を示し、このことは、神経突起伸長と緎維束形成のような基本 的な形態形成現象においてF3が機能することを示唆した。

\section{D-2. 細胞タイプ特異的発現と細胞内局在}

発生過程におけるマウス小脳皮質の免疫電子顕微鏡レベル での研究において(43)、我々は、F3の発現が明確に特定の細胞 に限局していることを見いだした。F3はPurkinje細胞では細胞体 にも神経突起にも全く存在しなかった。これと同じことが星細 胞についてもいえるが、顆粒細胞では細胞体には存在せず並行

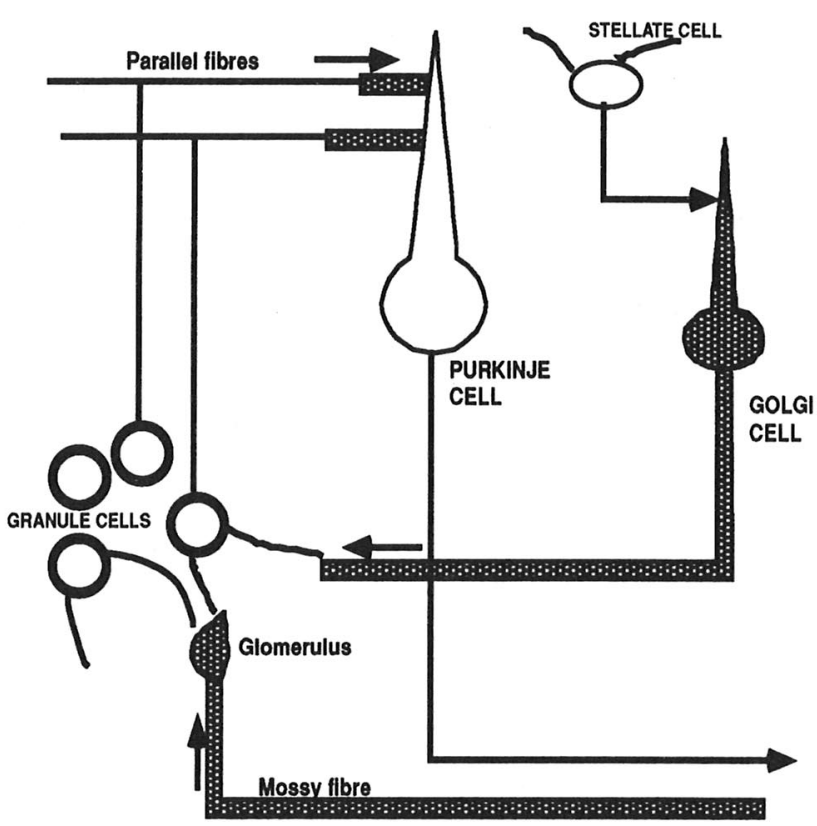

Fig. 5. Diagram of the F3 distribution on cerebellar cortex circuitry. Dotted regions represent areas of F3-immunoreactivity. Note the ubiquitous localization over Golgi neurons and the polarized distribution on parallel and mossy fibres. 
Trends in Glycoscience and Glycotechnology Vol. 5 No. 26 (November 1993) pp. 450-465

extensions, the parallel fibres, the cell bodies being almost completely F3-negative. In the same study F3 was never found on glial cells. From the above study it could be inferred that the $\mathrm{F} 3$ expression was regulated upon the cell type in the sense that the molecule could be detected only on a neuronal subpopulation (see Fig. 5).

The immunoelectron microscopy study revealed a third kind of regulation of $\mathrm{F} 3$ expression concerning the subcellular structures the molecule can be targeted to. As previously reported, on most differentiated neurons F3 was mainly targeted to the axonal level. However, studying the F3 distribution within the cerebellar cortex revealed that not all the neurons behaved in the same way. Golgi neurons, for instance, expressed the molecule at both the level of their cell bodies and extensions, thus suggesting either a cell type-specific sorting mechanism, or a diversity of the F3 molecular forms expressed by distinct neuronal cell types. In this last case it could be speculated that Golgi neurons expressed an F3 isoform provided of transmembrane and cytoplasmic regions responsible for its simultaneous distribution on the cell bodies and neurites. An F3 homologue bearing such structural features was initially described in chick brain and denominated contactin (44). However, the existence of such a transmembrane isoform was thereafter questioned and interpreted as a cloning artefact (36).

The study of the F3 ultrastructural distribution in the mouse cerebellar cortex revealed some peculiar features concerning its localization within the synaptic structures. Two synapses were studied in this respect: the axodendrytic junction between parallel fibers and Purkinje cells and the one joining mossy fibres terminals to granule cells within the complex structure called glomerulus. In both cases the molecule's distribution was asymmetric in the sense that it was restricted to the presynaptic compartments. The Purkinje cells dendrites were always F3-negative and the same was true for the granule cells dendritic spines connected to the mossy fibres terminals. An opposite situation was found for synaptic contacts between Golgi neurons and stellate cells. Here the molecule distribution was asymmetric in the sense that an F3 immunostaining was heavely present on the postsynaptic component (the Golgi cells dendrites) while no staining at all was found at the level of the presynaptic varicosities from stellate cells axons. Taken together, these data indicated that in the central synapses the F3 expression could be a property of either the pre- or postsynaptic components, but never of both of them. This experimental evidence was of key significance in defining the functional properties of the F3 dependent interactions which are likely to be heterophilic in nature (see below).

\section{E. F3 Functional Properties}

The above mentioned data were strongly suggestive for an F3 implication in interactions between nerve cells. Besides
繊維と呼ばれる軸索にほとんど局在していた。F3はグリア細胞 には見い出されなかった。以上の研究から、F3の発現が一部の 神経細胞にのみ検出されるというように細胞によって制御され ていることが考えられた(図5参照)。

免疫電顕を用いた研究から、F3が局在する細胞内構造に関 しての、F3発現の三番目の制御が明らかとなった。前述のよう に、分化した神経細胞ではF3はおもに軸索に局在した。しかし ながら、小脳皮質のF3の分布に関する研究により、すべての神 経細胞が同様とは言えないことが明らかになった。例えば、 Golgi神経細胞では、細胞体と突起に発現していることから、細 胞夕イプ特異的細胞内局在化機構もしくは異なるタイプの神経 細胞により多様なF3分子が発現されていることが示唆された。 この場合、Golgi神経細胞は同時に細胞体と神経突起に存在でき る膜貫通領域と細胞質領域を持ったF3アイソフォームを発現し ているかもしれない。そのような構造的特徴を持ったF3ホモ口 グが最初鷄の脳で報告され、contactinと名付けられた(44)。しか し、そのような膜貫通型アイソフォームはその後疑問視され、 クローニングにおける誤りであると解釈された(36)。

マウス小脳皮質の微細構造におけるF3の分布から、シナプ ス構造における分布に関するある特徵が明らかになった。この 点に関して二つのシナプスが研究された。平行緎維とPurkinje細 胞の間の軸索樹状突起間シナプスと系球体と呼ばれる複雑な構 造の中にある苔状繊維と顆粒細胞の間のものである。どちらの 場合でも、分子の分布はプレシナプス側に限局されているとい う意味で非対称であった。Purkinje細胞の樹状突起にはF3は決っ して見い出されず、苔状緎維終末とシナプスを作る顆粒細胞の 樹状突起にも同じことが言えた。逆の状況がGolgi神経細胞と星 細胞のあいだのシナプスについて見い出された。ここで、F3の 免疫染色がポストシナプス側に強く(Golgi 細胞樹状突起)、星細 胞軸索のプレシナプス側には全く見られず、分子の分布は非対 称となっていた。これらのデータは、中枢シナプスにおいてF3 発現はプレかポストのどちらかであり、両方ということはない ことを示している。この実験的事実は、ヘテロフィリックと考 えられるF3依存性の相互作用の機能特性を明らかにする上で基 本的に重要である(下記参照)。

\section{E. F3の機能特性}

上述のデー夕は神経細胞間の相互作用にF3が関与している ことを強く示唆する。F3は、シナプス結合を形成する時と場所 
being localized at the level of the nerve endings at the time and sites they form synaptic connections, F3 belongs to two families of surface glycoproteins presumed or demonstrated to mediate cell contacts formation: the immunoglobulin supergene family and the HNK-1 family.

To get insigths on the functional significance of the F3 expression during brain development, an experimental approach based on gene transfer techniques was devised. As a first step the full length F3 cDNA was espressed by transfection in the F3 negative CHO cells (45). This cell line was chosen because of its demonstrated ability to express at the cell surface GPI anchored molecules. Indeed, biochemically, the transfected molecule was found to share most of the features of native F3, including the presence of $N$-linked sugars and of a GPI anchorage. In addition, some more data concerning the F3 molecular forms and their biosynthesis could be collected. In CHO cells, F3 was expressed in two glycosylation forms (Fig. 6 lane b): the first one showed a low content in $N$-linked sugars as demonstrated by the lack of sensitivity to endoglycosidase $F$ digestion (lanes $\mathrm{c}, \mathrm{d}$ ). This form, which displayed an $\mathrm{Mr}$ of $135 \mathrm{kDa}$, behaved like an intracellular component as it was not affected by cell surface trypsinization. The second form, corresponding to the fully glycosylated molecule, displayed a $\mathrm{Mr}$ of about $142 \mathrm{kDa}, 7 \mathrm{kDa}$ higher than the molecule expressed in the brain (lane a) and was also found in a soluble, released form in the culture medium (lane e). Endoglycosidase F digestion (shown in lanes c, $\mathrm{d}$ ) demonstrated that these differences in $\mathrm{Mr}$ were essentially due to the posttranslational addition of $\mathrm{N}$ linked sugars and depended upon the peculiar glycosylation
で神経終末に局在していて、細胞接触を媒介すると仮定され証 明されている細胞表面糖タンパク質の二つのファミリー、イム ノグロブリンスーパージーンファミリーとHNK-1ファミ リー、に属する。

脳の発生過程におけるF3発現の機能的重要性を検討するた めに、遺伝子導入技術を用いた実験が考えられた。最初の段階 として、全長F3cDNAがF3を発現していないCHO細胞にトラン スフェクションされた(45)。この細胞は細胞表面にGPIアンカー した分子を発現させることができることから選ばれた。実際、 生化学的には、トランスフェクトされた分子はN型糖鎖とGPIア ンカーを持つことを含めて本来のF3の特徽のほとんどを示し た。さらに、F3分子の形や生合成に関するさらなるデータが得 られた。CHO細胞では、F3は二つのグリコシル化されたタイプ を発現した(図6レーンb)。第一の型は、エンドグリコシダーゼF 消化に感受性がないことによってわかるようにN型糖鎖を少し しか持っていなかった(レーンc、d)。この型は、 $135 \mathrm{kDa}$ の分子 量を示し、細胞表面トリプシン処理に非感受性である細胞内分 子のようであった。第二の型は、完全に糖付加された分子に相 当し、142 kDaであり、脳の分子より $7 \mathrm{kDa}$ 大きく(レーンa)、培 地中に放出された可溶性の分子としても検出された(レーンe)。 エンドグリコシダーゼF処理(レーンc、d)の結果より、分子量の 相違は主に翻訳後のN型グリコシル化と、CHO細胞特有のグリ

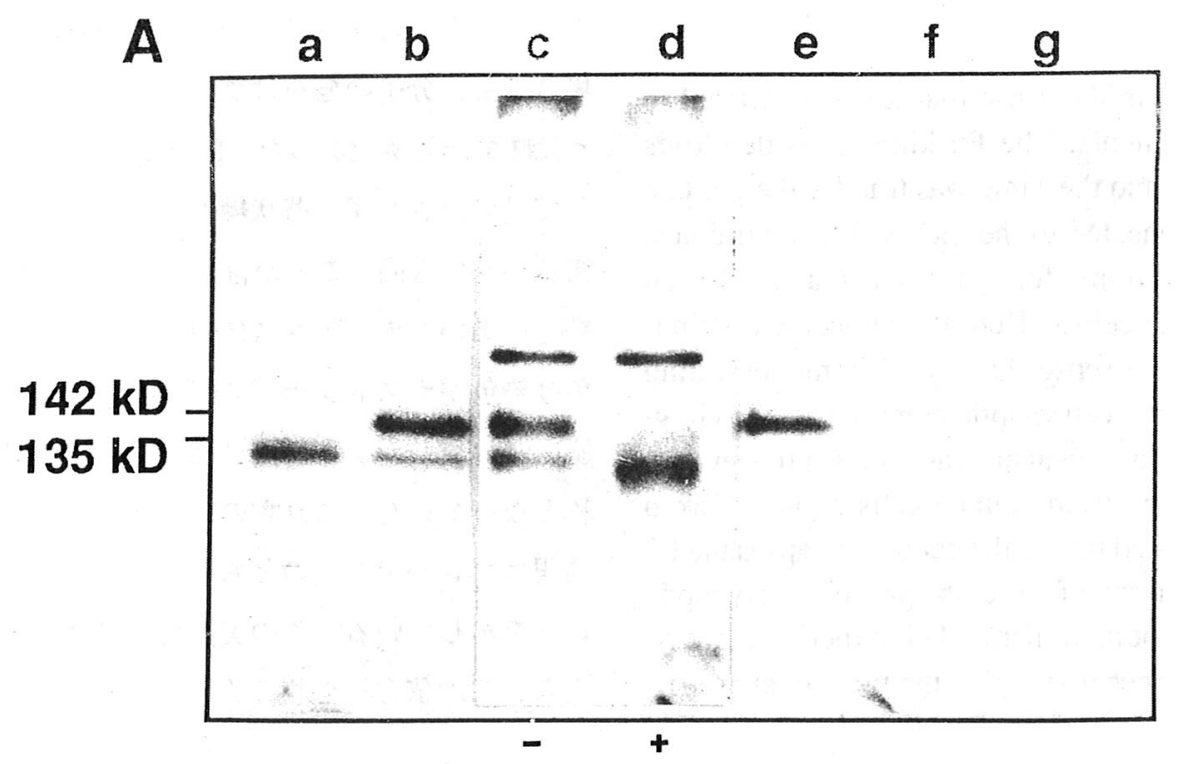

Fig. 6. Molecular forms of the $\mathrm{F} 3$ glycoproteins expressed by whole brain (a) and by $\mathrm{CHO}$ cells after transfection with the full length F3 cDNA (b-e) as detected by immunoprecipitation. The native molecule is composed by a single $135 \mathrm{kDa}$ chain (a) while the transfected molecule migrates as two 135 and $142 \mathrm{kDa}$ chains (b), the last one carrying $N$-linked sugars as shown by the $\mathrm{Mr}$ shift upon endoglycosidase $\mathrm{F}$ digestion $(\mathrm{c}, \mathrm{d})$. Only the $142 \mathrm{kDa}$ chain could be detected in the culture supernatant (e) while untransfected cells (f, $\mathrm{g}$ ) were completely F3-negative. 
Trends in Glycoscience and Glycotechnology Vol. 5 No. 26 (November 1993) pp. 450-465

behaviour displayed by $\mathrm{CHO}$ cells. A similar situation was indeed reported in the case of Myelin Associated Glycoprotein expressing CHO cells (46). By pulse chase, a precursor-product relationship between the two forms was demonstrated, the most glycosylated one representing the mature molecule expressed at the cell surface. The same glycosylation variants were also found in the brain (19), although this kind of molecular heterogeneity was there less evident because of the lower sugar content of the fully glycosylated form. The existence of an F3 intracellular low glycosylation variant allows to speculate that regulation of the molecule sugar content could provide a means of modulating the adhesive strength which, as demonstrated for NCAM (47), seems to depend upon the concentration of the adhesive glycoproteins at the cell surface.

The surface expressed fully glycosylated form was functional in that it was able to promote the adhesive behaviour of transfected cells. This led to the conclusion that changes in the overall sugars content occurring in the $\mathrm{CHO}$ cells did not affect the binding properties of F3. In this system F3 dependent interactions were found to involve the Immunoglobulin region since specific antibodies raised against the F3 Ig domains expressed as a fusion protein in Escherichia coli were able to disrupt, at least in part, F3 dependent cell adhesion.

In the same study the functional significance of the F3dependent interactions in the complex phenomena occurring during brain development was investigated by working out an in vitro model consisting of mixed cultures between $\mathrm{F} 3$ transfectants and primary neurons derived from the dorsal root ganglia. The differentiation behaviour of these cells, studied by image analysis, revealed a clear positive effect of this coculture procedure on neurite outgrowth which could be completely neutralized by F3 antibodies derived Fab fragments.

These data allowed the definition of F3 as a neuronal adhesion molecule and suggested that the positive effects it exerted on neurite outgrowth were adhesion dependent. The alternative explanation was that they resulted from the activation of transmembrane signalling pathways. To descriminate between these two possibilities an experimental approach was devised in which soluble F3, cleaved from the obtained transfectants by PIPLC treatment, was added to the culture medium of primary neurons and the effects of this procedure on neurite initiation and outgrowth followed by image analysis. The rationale for this experiment was to study the F3 effects on neurite outgrowth in the absence of F3-mediated cell adhesion. Under these conditions, statistically significant increases in neurite bearing cells and neurite length could be observed (Fig. 7). These data indicated that adding soluble F3 to the medium was as effective as the coculture procedure in promoting the neuronal differentiation and prompted the suggestion for a role of F3 as a soluble differentiation factor. This view was indeed supported by the existence of soluble $\mathrm{F} 3$ functional forms in the
コシル化によることが示された。実際同様な状況がMyelin Associated Glycoproteinを発現しているCHO細胞でも報告されている (46)。パルスチェイスの実験では、二種の分子の間の前駆体-生 成物の関係が明らかとなり、最もグリコシル化を受けている分 子が細胞表面に発現している最終的な分子であることが分かっ た。脳でも同様なグリコシル化状態の異なる分子が見つかって いるが(19)、脳ではこの種の分子多様性は、十分にグリコシル 化された分子でも糖付加量が少ないことからより分かりにく い。F3の細胞内少糖型の存在は、糖量の制御が接着力の調節の 方法となりえるかもしれないと考えさせる。NCAMについて証 明されているように(47)、細胞表面の接着糖タンパク質の濃度 に接着力は依存していると思われる。

細胞表面に発現された十分にグリコシル化された分子は、 トランスフェクトされた細胞の接着を促進し、機能することが できた。この事実から、CHO細胞における全体の糖付加量の変 化は接着に影響を与えないという結論が得られた。この系にお いて、大腸菌に融合タンパク質として発現させたF3のイムノグ ロブリン様ドメインに対する抗体が、少なくとも部分的にはF3 依存性細胞接着を阻害することができることから、F3依存性の 相互作用はイムノグロブリン様領域に関係していることがわかった。

脳発生の間に起こる複雑な現象の内のF3依存性の相互作用 の重要性については、F3トランスフェクタントと後根神経節の 初代培盖細胞の混合培養よりなるin vitroモデルを用いて研究し た。画像解析によりこれらの細胞の分化を観察すると、神経突 起伸長に対する明らかな正の効果が見られ、これはF3に対する Fab抗体により完全に中和された。

これらのデータは、F3が神経細胞接着分子であることを示 し、神経突起伸長が接着依存性であることを示唆すると考えら れた。他の説明としては、膜を介した情報伝達経路の活性化が 考えられる。この二つの可能性を区別するために、トランス フェクタントからPIPLCで遊離させた可溶性のF3を初代培養神 経細胞の培地に加え、神経突起伸長の開始と伸長への効果を画 像解析するという実験が考案された。この実験の目的は、F3を 介する細胞接着なしに神経突起伸長に対するF3の効果を見るこ とであった。その結果、突起を持つ細胞の数と突起の長さの統 計的に有意な増加が見られた(図7)。このデー夕は、培地に可溶 性F3を加えることが、神経細胞の分化を誘導する混合培養と同 ビ効果を持つことを示し、F3の可溶性分化ファクターとしての 役割を示唆した。この考えは、実際、脳脊䯣液と脳の画分にお いてF3が可溶性分子として存在することにより支持された(19、 
cerebrospinal fluid and in brain fractions of different solubility $(19,48)$. The hypothesis was therefore put forward that the molecule could be released from the neuronal cell surface and exert, as a soluble differentiation factor, its biological effects at a distance from the site of biosynthesis or delivery (48).

In the same study two kinds of experimental evidences concerning the nature of the F3 dependent interactions were collected. First, the stimulation of neurite outgrowth occurred in the absence of any effect on cell adhesion thus supporting the view that activation of second messenger pathways triggered by the F3 interaction with a transmembrane receptor was involved in the molecule's biological effect. In addition F3 dependent interactions were confirmed to be heterophilic in nature as demonstrated by the ability of the isolated molecule to promote neurite outgrowth from $\mathrm{F} 3$ negative neurons, thus suggesting the implication of a structurally and immunologically different receptor.

One of the central questions of the F3 biology concerns therefore the identification of the molecule(s) F3 is able to interact with in exerting its biological effects. The study of the F3 receptor and of its chicken relative F11 led to the identification of a large set of putative ligands whose kind of interactions,"in cis" or "in trans" still wait to be elucidated in functional terms. First, the extracellular matrix glycoprotein, restrictin (49) was found to copurify with F11. The denomination of this molecule lies in its restricted distribution in some region of the central nervous tissue including the spinal cord. As demonstrated by cDNA cloning restrictin is a complex multidomain glycoprotein bearing four distinct types of structural motifs including a cysteine rich segment at the N-termi-
48)。そこで、F3分子は神経細胞の表面から放出され、可溶性の 分化ファクターとして生合成された所、もしくは運ばれた所 から離れた所で生物学的効果を示すという仮説が提唱 された(48)。

F3依存性の相互作用の性質に関する二つの実験的証拠が得 られた。第一は、細胞接着なしに神経突起伸長が起こったこと で、これは、膜レセプターとF3の相互作用によりセカンドメッ センジャー経路が活性化され、F3分子の生物学的効果が生じる という考えを支持した。さらに、精製したF3分子がF3を持たな い神経細胞の突起を伸長させることができることから、F3依存 性の相互作用はへテロフィリックであることが確かめられ、こ れは、構造的にも免疫学的にも F3と異なるレセプターの存在を 示唆した。

F3の生物学的役割についての中心的課題は、F3が生物学的 効果を示す際に相互作用する相手の分子を同定することであ る。F3とそのニワトリのホモログであるF11のレセプターに関 する研究から、機能がまだ明らかになっていないシスまたはト ランスに作用する多くのリガンド候補が同定された。最初に、 細胞外マトリックス糖タンパク質restrictin(49)が、F11と一緒に 精製された。この分子の名前は、この分子が脊䯣を含む中枢神 経組織のある領域に限局して存在することからきている。 cDNAクローニングの結果より、restrictinはN末端のシステイン に富む部分、4.5個のEGF様構造、9個のファイブロネクチンIII
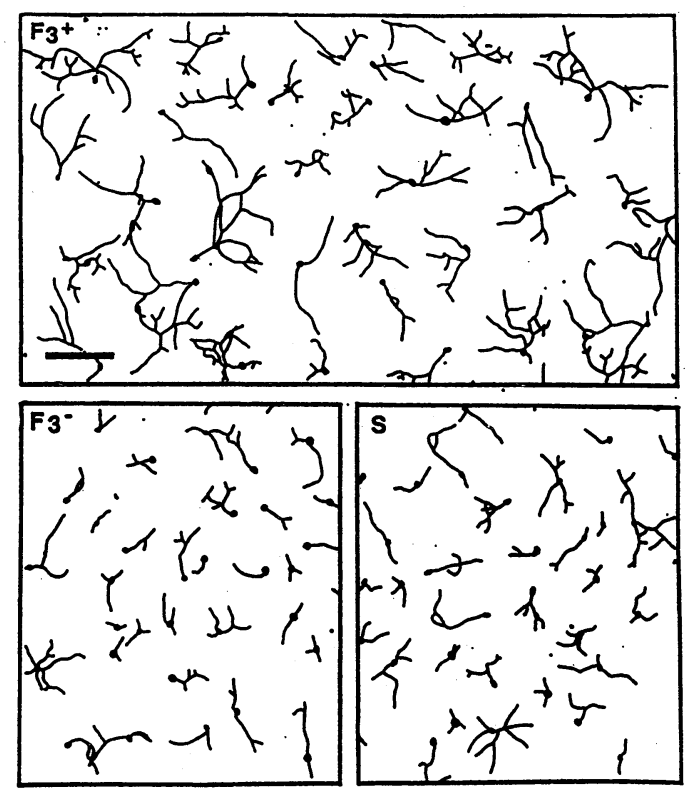

Fig. 7. Morphological analysis of isolated neurons from mouse dorsal root ganglia grown for $24 \mathrm{hr}$ in the presence of medium derived from cultures of $\mathrm{F3}$ transfectants in $\mathrm{CHO}$ cells (F3+), from cultures of parental cells (F3-) or in the presence of standard medium (S). Bar $=300 \mathrm{um}$. 
nus, 4.5 EGF-like and 9 fibronectin type III repeats. At the Cterminus the molecule bears sequences homologous to $\alpha$ - and $\beta$-fibrinogen (50).

The exact functional significance of the F11/restrictin interaction still waits to be elucidated. On the other hand, more insigths on the functional consequences of the F3 mediated molecular interactions were obtained in the mouse were the main $\mathrm{F} 3$ receptor was identified in the oligodendrocyte derived, extracellular matrix component firstly called $\mathrm{J} 1 \quad 160-180$ and now renamed janusin $(51,52)$. Recently, cDNA cloning revealed that restrictin and janusin are species homologues, thus suggesting their implication in similar functions (53).

The interaction between F3 and janusin was a biphasic event in that it included a first adhesion step (as shown by the ability of F3 transfectants to adhere to a janusin substrate) followed by a repellent response which could only be exerted by the molecule embedded in its native environment as is the case for the cerebellar granule cells. In this cell type the initial F3/ janusin adhesion event was followed by an avoidance response leading to detachment of the cell bodies from the substrate and inhibition of neurites outgrowth. Adhesion and adhesion inhibition have both been considered as parts of the complex functional events leading to neurite extension (11) and a molecule mediating both these functional effects could lend itself especially well to control such a complex event as the extension of neuronal processes. However, more data concerning the machinery activated by $\mathrm{F} 3$ interactions are necessary before the complex role this molecule plays in neural morphogenesis become clear. The study of the putative receptors to F3/11 revealed the ability of this molecule to interact with $\mathrm{NgCAM}$ via a site located within the first two immunoglobulin domain (54). In addition the molecule exhibited an affinity for the extracellular matrix glycoprotein tenascin (55). These data clearly indicated F3 as a multidomain protein able to mediate different kinds of molecular interactions via its distinct domains. The functional significance of these multiple interactions remain to be elucidated. They could configure "trans" interactions linking surface glycoproteins to their receptors or "cis" associations as reported in the case of the two best known adhesive glycoproteins of the nervous tissue, L1 and NCAM (56). These two glycoproteins interact in the plane of the membrane in a carbohydrate dependent manner (57) and their association is provided of a definite functional significance in controlling their adhesive behaviour.

The structural and functional association between distinct adhesive glycoproteins could provide an explanation to their redundancy. Surface ligands bearing similar overall structures but also belonging to distinct gene families are often co-expressed at the level of the same neural cells, at least in some developmental stages. The "cis" interaction between these different adhesive glycoproteins would be the basis of the
型構造を含む四つの異なるモチーフ持つ複雑なマルチドメイン 糖タンパク質であることが分かっている。C末には、 $\alpha$-と $\beta$ フィブリノーゲンに類似の配列を持つ(50)。

F11 と restrictinの相互作用の重要性はまだ明らかではない。 他方、F3を介する相互作用の重要性についての情報が、マウス において得られた。主要なF3レセプターとしては、最初J1 160180 と呼ばれ現在janusin と呼ばれているオリゴデンドロサイト由 来の細胞外マトリックス分子が同定された $(51,52)$ 。最近、 cDNAクローニングから restrictin と janusinは種間ホモログである ことが示され、類似の機能を持つことが示唆された(53)。

F3とjanusinの相互作用は、二相性を示し、最初の接着段階 (F3トランスフェクタントがjanusin基質へ結合することにより示 される)に続き、小脳顆粒細胞上にある分子のような本来の環境 にある分子にのみ示すことができる反発が現れた。この細胞に おいて、最初のF3 と janusinの接着に続き、基質からの細胞体の 遊離と神経突起伸長の阻害を導く回避反応が起きた。接着と接 着阻害は突起伸長を促進する複雑な機構のうちの一部と考えら れ(11)、二種類の機能を媒介できる分子は、神経突起伸長のよ うな複雑な現象を制御するのに特に有用となると思われる。し かしながら、F3相互作用によって活性化される仕組みに関する さらなるデータが、神経系の形態形成におけるこの分子の複雑 な役割を解明するためには必要である。F3/11に対するレセプ タ一候補に関する研究により、この分子が最初の二つのイムノ グロブリン様ドメインのある部位を介してNgCAMと相互作用 することが明らかになった(54)。さらに、この分子は細胞外マ トリックス糖タンパク質であるtenascinに対して接着性を示した (55)。これらのデータはF3がマルチドメインタンパク質とし て、異なるドメインを介して異なる種類の分子間相互作用に関 与できることを明確に示していた。このような多重の相互作用 の重要性はまだ明らかになっていない。それらは、細胞表面糖 タンパク質のレセプターに対する"トランス"相互作用、もしく は神経組織の最もよく知られた二つの接着分子、L1とNCAMの 場合に報告されている(56)ような"シス"会合を作り出すことがて きるかもしれない。これらの二つの糖タンパク質は糖鎖依存性 に膜平面の中で相互作用し(57)、この会合は接着を制御すると いう明確な機能上の重要性を持つ。

異なる接着糖タンパク質の構造的、機能的会合は、それら の分子の過㮃な存在を説明できるかもしれない。同様な全体構 造を持ち、異なる遺伝子ファミリーに属している細胞表面りガ ンドは、少なくともある発生段階において同じ神経系細胞にし ばしば一緒に発現している。これらの異なる接着糖タンパク質 
Trends in Glycoscience and Glycotechnology Vol. 5 No. 26 (November 1993) pp. 450-465

so called "assisted homophilic" cell adhesion (56) in which structurally distinct surface components cooperate in the definition of a cell surface binding site. While providing a tentative structural explanation for the functional cooperation between different adhesive glycoproteins, this mechanism would also require a precise regulation of the expression of their genes in distinct cell types or developmental stages. It could be suggested that the expression of molecules involved in "assisted homophilic" binding would be regulated in concert in a way to provide the cell surface of definite adhesive specificity. Unfortunately very little is known about the control of gene expression for the morphoregulatory molecules. Studies on the transacting factors involved in the regulation of the Neural Cell Adhesion Molecule, NCAM revealed the involvement of homeodomains containing proteins (58) thus suggesting the implication of the adhesive glycoproteins in a complex developmental program (2).

On the basis of the presented results a morphogenetic role can also be proposed for the adhesive glycoproteins expressed at the axonal level thus suggesting that regulation of their expression is of central importance in some definite aspects of neural morphogenesis. Till now $\mathrm{L} 1$ is the only axonal adhesive glycoprotein whose genomic organization has been elucidated (59). The study of the genes encoding the Ig/FNIII molecules and their regulatory regions will certainly provide important informations concerning cis and trans factors involved in the molecular control of neural morphogenesis. However, besides the trascriptional regulation of their expression, special attention should be also devoted to the significance of the posttranslational modifications of the morphoregulatory molecules and in particular to the regulation of the biosynthesis of their sugar moiety. The best exemple in this respect is offered by the already mentioned HNK-1 epitope. This sugar is shared only by a subpopulations of NCAM (16), MAG (60), L1 (61) and Po (62) glycoproteins therefore suggesting that it can be independently modulated from the protein backbone. The mechanism regulating HNK-1 expression on a specified molecule is poorly understood. However it is likely to involve the regulation of the expression of a specific glycosyltransferase which catalyzes the attachment of the HNK-1 determinant on the sugar moiety. Studies on the functional and spatial expression of the HNK-1 glycosyltransferase will provide important cues on the biological significance of the HNK-1 expression during brain development. A recent study demonstrated an alternate pattern of $\mathrm{HNK}-1$ expression on some rhombomers, reminiscent of the one of mouse Hox and Krox genes (63) which encode homeobox and zinc finger-containing transcription factors, respectively (64). While stregthening the hypothesis of the morphogenetic relevance of HNK-1 expression, these data allow to point to the regulation of the HNK-1 glycosyltransferase expression by transcription factors as a rel-
の"シス"相互作用は、構造的に異なる表面分子が特定の細胞表 面で協同して働くという、いわゆる"assisted homophilic"細胞接 着(56)に基づくのかもしれない。異なる接着糖タンパク質間の 機能上の協同について仮説をつくることができるが、その機構 は、異なる細胞や異なる発生段階におけるこれらの分子の発現 の正確な制御を要求すると思われる。"assisted homophilic"結合 に関与する分子の発現は、特定の接着特異性を持った細胞表面 を作り出すように協調的に制御されると考えられる。不運にも 形態形成制御分子については、遺伝子発現の制御についてほと んどわかっていない。Neural Cell Adhesion Molecule、NCAMの 発現制御にトランスに働くファクターの研究から、ホメオドメ インを持つタンパク質の関与が示され(58)、複雑な発生プログ ラムにおける接着糖タンパク質の役割が示唆された(2)。

これまでの結果に基づいて、軸索に発現している接着糖夕 ンパク質が形態形成に関わることを提唱することができる。こ のことは、これらの分子の発現制御が、神経系の形態形成のあ る面において非常に重要であることを示唆する。現在までのと ころ、L1は遺伝子構造が明らかになっているただ一つの軸索接 着糖タンパク質である(59)。Ig/FNIII分子とその発現制御部位を コードしている遺伝子についての研究は、神経系の形態形成の 制御に関与するシスとトランスのファクターに関する重要な情 報を与える。しかしながら、発現の転写制御の他にも、形態制 御分子の翻訳後の修飾の重要性、特に糖部分の生合成制御に注 目すべきだと思われる。この点における最もよい例は、既に述 べたHNK-1エピトープに関するものである。この糖鎖構造は、 NCAM(16)、MAG(60)、L1(61)、Po(62)などの一群の糖タンパ ク質に共通に存在する。それ故に、このエピトープの発現は夕 ンパク質構造とは独立して調節されていると考えられる。特定 の分子上のHNK-1発現の制御機構はよく分かっていない。しか しながら、糖鎖構造上のHNK-1エピトープの合成に関わる特異 的糖転移醳素の発現制御が関係していると考えられる。HNK-1 合成に関わる糖転移䤉素の機能的、空間的発現に関する研究 は、脳の発生におけるHNK-1発現の生物学的重要性に関する有 力な手がかりを与えてくれると思われる。最近の研究により、 ホメオボックスとZnフィンガー転写因子(64)をコードするマウ スHoxとKrox遺伝子(63)の発現パターンを思い起こさせるよう なロンボメアでのHNK-1の発現パターンが示された。これによ り、HNK-1発現が形態形成に関係しているという仮説が強めら れたが、このデー夕は、神経系の発生に関わる転写因子が、 HNK-1エピトープ合成に関与する糖転移酵素の発現を制御して 
evant molecular cue in neural development.

\section{Acknowldgements}

Most of the results presented in the present review concerning the structural and functional properties of the F3 glycoprotein were obtained in the laboratories of Dr. C. Goridis at the "Centre d'Immunologie INSERM-CNRS de MarseilleLuminy" and of Dr. G. Rougon at the "Laboratoire de Biologie de la Differenciation Cellulaire" in Marseille. The work performed in Bari was supported by a grant from Telethon-Italy to G.G. The work done in Marseille was supported by INSERM (CRE 92-95) and AFM grants to GR.
いると考えさせる。

\section{三菱化成生命科学研究所 ·脳神経化学研究室}

佐野 慎一郎訳

\section{References}

1. Edelman, G.M. (1986) Ann. Rev. Cell Biol. 2, 81-116

2. Edelman. G.M.(1992) Develop. Dynamics 193, 2-10

3. Lagenaur, C., and Lemmon, V. (1987) Proc. Natl. Acad. Sci. USA., 84, 7753-7757

4. Doherty, P., Barton, C.H., Dickson, G., Seaton, P., Rowett, L.H., Moore, S.E., Gower, H.J., and Walsh, F.S. (1989) J. Cell Biol. 109, 789-798

5. Doherty, P., and Walsh, F.S. (1992) Curr. Opin. Cell Biol. 2, 595-601

6. Doherty, P., Rowett, L.H., Moore, S.E., Mann, D.A., and Walsh, F.S. (1991) Neuron, 6, 247-258

7. Lander, A.D.(1990) Curr. Opin. Cell Biol. 2, 907-913

8. Doherty, P., Ashton, S.V., Moore, S.E., and Walsh, F.S. (1991) Cell, 67, 21-33

9. Doherty, P., Cohen J., and Walsh F.S. (1990) Neuron 5, 209-219

10. Patterson, P.H. (1988) Neuron 1, 263-267

11. Keynes, R., and Cook, G. (1990) Cell 62, 609-610

12. Gennarini, G., Rougon, G., Vitiello, F., Corsi, P., Di Benedetta, C., and Goridis, C. (1989) J. Neurosci. Res. 22, 1-12

13. Bon, S., Meflah, K., Musset, F., Grassi, J., Massoulié, J. (1987) J. Neurochem. 49, 1720-1731

14. Kruse, J., Mailhammer, R., Wernecke, H., Faissner, A., Sommer, I., Goridis, C., and Schachner, M. (1984) Nature 311, 153-155

15. Riopelle, R.J., Mc Garry, R.C., and Roder, J.C. (1986) Brain Res. 367, 20-25

16. Needhom, L., and Schnaar, R. (1993) J. Cell Biol. 121, 397-408

17. Chou, D.K.H., Ilyas, A.A., Evans, J.E., Costello, C., Quarles, R.H., and Jungawala, F.B. (1986) J. Biol. Chem. 261, 11717-11725

18. Hynes, M., Dodd, J., and Jessel, T.(1989) In:"Neurobiology of Glycoconjugates". Margolis, R.U., and Margolis, R.K. Eds. Plenum Publish ing Corp. New York, 337-365

19. Gennarini, G., Cibelli, G., Rougon, G., Mattei, M.G., and Goridis, C. (1989) J. Cell Biol. 109, 775-788

20. Williams, A.F. (1987) Immunol. Today 8, 298-303

21. Williams, A.F., and Barclay, A.N. (1988) Ann. Rev. Immunol. 6. 381-405

22. Amzel, M.L., and Poljak, R.J. (1979) Ann. Rev. Biochem. 48, 961-979

23. Odermatt, E., Tamkun, J.W., and Hynes, R.O. (1985) Proc. Natl. Acad. Sci. USA 82, 6571-6575

24. Obara, M., Kang, M.S., and Yamada, K.M. (1988) Cell 53, 649-657

25. Baron, M., Main, A.L., Driscoll, P.C., Mardon, H.J., Boyd, J., and Campbell, I.D. (1992) Biochemistry 31, 2068-2073

26. Leahy, D.J., Hendrickson, W.A., Aukhil, I., and Erickson, H.P. (1992) Science 258, 987-991

27. Main, A.L., Harvey, T.S., Baron, M., Boyd, J., and Campbell, I.D. (1992) Cell 71, 671-678

28. Sonderegger, P., and Rathjen, F. (1992) J. Cell Biol. 119, 1387-1394

29. Moos, M., Tacke, R., Scherer, D., Teplow, K., Fruh, K., and Schachner, M. (1988) Nature 334, 701-703

30. Lindner, J.F., Rathjen, F.G., and Schachner, M. (1985) Nature 305, 427-430

31. Fischer, G., Kunemund, V., and Schachner, M. (1986) J. Neurosci. 6, 605-612

32. Stallcup W.B., and Beasley L. (1985) Proc. Natl. Acad. Sci. USA 82, 1276-1280

33. Burgoon, M.P., Grumet, M., Mauro V., Edelman, G.M., and Cunningham, B.A. (1991) J. Cell Biol. 112, 1017-1029

34. Furley, A.J., Morton, S.B., Manalo, D., Karagogeos, D., Dodd J., and Jessel, T.M.(1990) Cell 61, 157-170

35. Zuelling R.A., Rader C., Schroeder, A., Kalousek, M.B., von Bolen und Halbach, F., Osterwalder, T., Inan, C., Stoeckli, E.T., Affolter, H.U., Fritz, A., Hafen, E., and Sonderegger, P. (1992) Eur J. Biochem. 204, 453-463

36. Brummendorf, T., Wolff, J.M., Franck, R., and Rathjen, F. G. (1989) Neuron 2, 1351-1361

37. Ferguson, M.A., and Williams, A.F. (1988) Ann. Rev. Biochem. 57, 285-320

38. Théveniau, M., Durbec, P., Gennarini, G., Wood, J.N., and Rougon, G. (1992) J. Cell. Biochem. 48, 61-72

39. He, H.T., Finne, J., and Goridis, C. (1987) J. Cell Biol. 105, 2489-2500

40. Gower, H.J., Barton, C.H., Elsom, V.L., Thompson, J., Moore, S.E., Dickson, G., and Walsh, F.S. (1988) Cell 55, $955-964$

41. Rodriguez-Boulan, E., and Powell, S.K. (1992) Ann. Rev. Cell Biol. 8, 395-427

42. Gennarini, G., Rougon, G., and Goridis, C. (1990) Acta Histochemica supp. 37, 65-69

43. Faivre-Sarrailh, C., Gennarini, G., Goridis, C., and Rougon, G.(1992) J. Neurosci. 12, 257-267

44. Ranscht, B. (1988) J. Cell Biol. 107, 1561-1573

45. Gennarini, G., Durbec, P., Boned, A., Rougon, G., and Goridis, C. (1991) Neuron 6, 595-606

46. Johnson, P.W., Abramow-Newerly,W., Seilheimer, B., Sadoul, R., Tropak, M.B., Arquint, M., Dunn, R.J., Schachner, M., and Roder, J.C. 
(1989) Neuron 3, 377-385

47. Edelman, G.M. (1986) Science192, 218220

48. Durbec, P., Gennarini G., Goridis C., and Rougon G. (1992) J. Cell Biol. 117, 877-887

49. Rathjen, F.G., Wolff, J.M., and Chiquet-Ehrismann, R. (1991) Development 113, 151-164

50. Norenberg, U., Wille, H., Wolff, J.M., Frank, R., and Rathjen, F.G. (1992) Neuron 8, 849-863

51. Pesheva, P., Spiess, E., and Schachner, M. (1989) J. Cell Biol. 109, 1765-1778

52. Pesheva, P., Gennarini, G., Goridis, C., and Schachner, M. (1993) Neuron 10, 69-82

53. Fuss, B., Wintergest, E.S., Bartsch U., and Schachner, M. (1993) J. Cell Biol. 120, 1237-1249

54. Brummendorff, T., Hubert, M., Treubert, U., Leuschner, R., Tarnok, A., and Rathjen, F.G. (1993) Neuron 10, 711-727

55. Zisch, A.H., D'Alessandri, L., Rancht, B., Falchetto, R., Winterhalter, K.H., and Vaughan, L. (1992) J. Cell Biol. 119, $203-213$.

56. Kadmon, G., Kowitz, A., Altevogt, P., and Schachner, M.. (1990) J. Cell Biol. 110, 193-208

57. Kadmon, G., Kowitz, A., Altevogt, P., and Schachner, M. (1990) J. Cell Biol. 110, 209-218

58. Hirsch, M.R., Valarché, I., Deagostini-Bazin, H., Pernelle, C., Joliot, A., and Goridis, C. (1991) FEBS Lett. 287, $197-202$

59. Kohl, A., Giese, K.P., Mohajeri, M.H., Montag, D., Moos, M., and Schachner, M. (1992) J. Neurosci Res. 82, 167-177

60. Poltorak, M., Sadoul, R., Keilhauer, G., Landa, C., Fahrig, T., and Schachner, M. (1987) J. Cell Biol. 105, $1893-1899$

61. Faissner, A. (1988) Neurosci. Lett. 83, 327-332

62. Burger, D., Simon, G., Perruisseau, G., and Steck, A. (1990) J. Neurochem. 54, 1569-1575

63. Kusatani, S.C.(1991) Dev. Biol. 114, 215-219

64. Kessel, M., and Gruss, P.(1990) Science 249, 374-379

Received on July 19, 1993, accepted on July 26, 1993 